
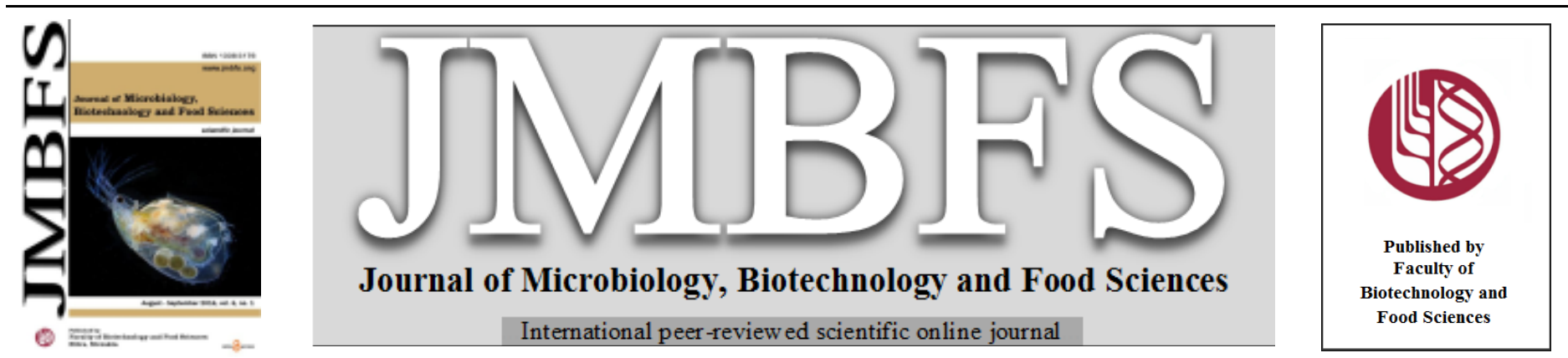

\title{
MYCOTOXIN-PRODUCING PENICILLIUM AND OTHER FUNGI ISOLATED FROM SLOVAK WINE GRAPES AT VARIOUS STAGES OF MATURATION
}

\author{
Soňa Felšöciová \\ Address(es): Ing. Soňa Felšöciová, PhD.
}

Slovak University of Agriculture, Faculty of Biotechnology and Food Sciences, Department of Microbiology, Tr. A. Hlinku 2, 94976 Nitra, Slovak Republic; + 4210376415813 .

*Corresponding author: sona.felsociova@uniag.sk

doi: 10.15414/jmbfs.2016.6.1.747-751

\section{ARTICLE INFO}

Received 6. 4. 2016

Revised 4. 5. 2016

Accepted 12. 5. 2016

Published 1. 8. 2016

Regular article

OPEN $\partial_{\text {ACCESS }}$

\begin{abstract}
The aim of the study was to monitor the mycobiota in grape samples at 3 maturation stages (pea berry, early veraison and ripe berry) and to test the ability of selected Penicillium strains to produce mycotoxins in year 2014. Grapes came from Nitra wine growing region, Šintava subregion and were analyzed by plating methods. From Devín grape variety the 339 strains were detected and identified. The most abundant genera found by descending order were Alternaria (42.8\%), Cladosporium (24.2\%) and Epicoccum (10.0\%). Penicillium expansum was isolated from all 3 maturation stages but in low average relative density (1.2\%). From Frankovka modrá (Frankish) grape variety the 562 strains were detected and identified. The most abundant genera found by descending order were Alternaria (30.6\%), Cladosporium (21.3\%) and Penicillium (20.3\%). Totally were identified 8 species of the genus Penicillium. The most important species, on the basis of the isolation from all maturation stages and relative density, was P. expansum. Selected isolates of Penicillium species were tested for their toxigenity, according to thin layer chromatography method. In total 14 Penicillium strains representing 3 potentially toxigenic species were tested for their toxigenic ability, namely P. expansum, P. griseofulvum and P. chrysogenum. Out of 14 strains, $64 \%$ produced et least one mycotoxin as revealed by the method used here.
\end{abstract}

Keywords: Penicillium, wine grapes, maturation stages of grapes, TLC method, mycotoxins

\section{INTRODUCTION}

The grape microbial ecosystem is composed of highly diverse microorganisms, including yeasts, bacteria and fungi (Barata et al., 2012). Molds are ubiquitous with various genera commonly found on grapes (Rosa et al., 2002). Mold growth plays an important role in spoilage of grapes, of their pathogenicity to the harvested products, in the physical and chemical stability as well as the sensory properties of the future wine. Fungal spoilage of grapes causes substantial financial losses to growers and processors and may pose a health threat to the consumer if the contaminating fungi produce mycotoxins.

Contamination of grapes by different moulds occurs during preharvesting, harversting and grape processing. The fungal growth begins in grapes if temperature and humidity are suitable. Rotting and spoilage of grape berries before harvest can be caused by a variety of fungal species such as Alternaria spp., Aspergillus spp., Botrytis cinerea, Cladosporium spp., Eurotium spp., Penicillium spp. and Rhizopus spp. These genus are regarded as the main natural contaminants of grapes (Valero et al., 2005).

Changes in the total fungal population over the growing season have been observed. At berry set, fungal populations were large in all vineyards, regardless of the grape variety, but the predominant species differed (Bau et al., 2005; Bellí et al., 2006; Gomez et al., 2006; Melki Ben Fredj et al., 2007). Harvest was considered to be a critical period in the growing season for fungal development. A decrease in acidity, sugar accumulation, the berry cuticle becoming brittle, damage to berries and an adaptation of mycotoxin-producing fungi to hot and humid environments may account for the abundance of fungi and the high levels of mycotoxins (Clouvel et al., 2008; Lasram et al., 2012).

It is important to identify fungal contaminants in grapes because some moulds can grow and produce mycotoxins while certain yeasts and moulds can cause infections or allergies (Tournas and Katsoudas, 2005). The mycotoxin production is characteristic of the species and therefore by identifying the species one can predict potential mycotoxin hazards. The major mycotoxigenic fungi that attack harvested fruits and vegetables are Aspergillus, Penicillium and Alternaria species - and the mycotoxins produced by them in the host tissues, e.g., aflatoxins, ochratoxin A, patulin and alternaria toxins (Barkai-Golan, 2001).
Penicillium species are filamentous fungi that are widely distributed in nature and can spoil food and food products (Samson and Frisvad, 2004). Most Penicillium spp. are ubiquitous soil fungi that are associated with organic matter in nature, however, their presence as epiphytes on grapes has also been reported. Some species of Penicillium are important plant pathogens that cause considerable economic losses in apples, citrus, grapes, and other unrelated crops in different regions of the world (Donoso and Lattore, 2006). For instance, P. expansum Link is an aggressive, destructive postharvest pathogen and a mycotoxigenic species that has been frequently reported as the cause of blue mold in stored apples and pears and causes a large part of the economic losses that occur during storage and shipment (Barkai-Golan, 2001). The species of Penicillium have gained attention as grapevine pathogens that cause blue mold decay at harvest (Donoso and Latorre, 2006).

The objective of the study was to identify the natural mycobiota in wine grapes collected from the Nitra wine region, with focus on genera Penicillium. In the vineyard, samples were taken at the pea-sized berry stage, at the beginning of berry ripening (veraison), and at harvest stage. Special emphasis was laid on the ability of some potentially toxigenic penicillia to produce some selected mycotoxins by thin layer chromatography method (TLC).

\section{MATERIAL AND METHODS}

\section{Study area and samples}

Slovak republic has 6 distinct wine-growing zones (the Small Carpathians, the Southern Slovak, the Nitra, the Central Slovak, the Eastern Slovak and the Tokaj wine regions). They spread from the west to the east of the country along its southern and south-western borders. We had samples from the Nitra wine region, Šntava subregion, village Báb. Two samples -1 of white grape variety Devín and

1 of blue grape variety Frankovka modrá at 3 maturation stages were mycologically analyzed. One sample of a wine grape variety was represented by three subsamples of wine grapes, which were sampled in left, middle and right part of the vineyard. Samples were collected from July 2014 to October 2014, in the maturation stages corresponding to pea berry (early July), early veraison 
(middle August) and harvest (middle October). The berries from the vineyards sampled were generally in good condition without visible damage. The samples of wine grapes were taken to sterile plastic bags and transported to a mycological laboratory for immediate processing.

\section{Mycological analysis of grapes}

The detection of fungi in grape samples was made by plating methods without surface disinfection. A total of 50 berries (6 - 7 healthy berries per bunch) from each sample were randomly selected and plated on Dichloran Rose Bengal Chloramphenicol agar medium (DRBC, MERCK, Germany), and incubated at $25{ }^{\circ} \mathrm{C}$ in the dark for one week. The sporeproducing filamentous fungi detected were identified according to the manuals of Samson et al. (2002a, 2010). Penicillium strains were isolated and cultivated in MEA (Malt extract agar, Samson et al., 2010), CYA (Czapek yeast agar, Samson et al., 2010), CREA (Creatine-Sucrose agar, Samson et al., 2010) and YES (Yeast Extract agar, Samson et al., 2010) to obtain pure cultures and identify further species. Genus Penicillium was identified to species level based on morphological characters according to special mycological literature of Pitt and Hocking (1997), Samson and Frisvad (2004) and Samson et al. (2002a, 2010).

\section{Results evaluation}

The obtained results were evaluated and expressed according to relative density (RD). The relative density $(\%)$ is defined as the percentage of isolates of the species or genus, occurring in the analyzed sample (Guatam et al., 2009). These values were calculated according to González et al. (1999) as follows:

$$
\mathrm{RD}(\%)=(\mathrm{ni} / \mathrm{Ni}) \times 100
$$

$\mathrm{ni}$ - number of isolates of a species or genus; $\mathrm{Ni}$ - total number of isolated fungi.

\section{Toxinogenity analysis}

Toxinogenity of selected isolates was screened in in vitro conditions by means of thin layer chromatography (TLC) according to Samson et al. (2002b), modified by Labuda and Tančinová (2006). Extracellular metabolites - citrinin, patulin and griseofulvin were carried out on YES agar and intracellural roquefortin $\mathrm{C}$ and cyclopiazonic acid on CYA agar. A few pieces of mycelium with approximate size $5 \times 5 \mathrm{~mm}$ were cut from colonies and placed in an Eppendorf tube with 500 $\mu \mathrm{L}$ of chloroform: methanol $-2: 1$ (Reachem, Slovak Republic). The content of the tubes was stirred for $5 \mathrm{~min}$. by Vortex Genie ${ }^{\circledR} 2$ (MO BIO Laboratories, Inc - Carlsbad, CA, USA). The volume $30 \mu \mathrm{L}$ of liquid phase of extracts along with $10 \mu \mathrm{L}$ standards (Sigma, Germany) was applied on TLC plate (Alugram ${ }^{\circledR}$ SIL G, Macherey - Nagel, Germany). The plate was put into TEF solvent (toluene: ethyl acetate: formic acid - 5:4:1, toluene - Mikrochem, Slovak Republic; ethyl acetate and formic acid - Slavus, Slovak Republic). After elution the plate was air-dried. Identification of the metabolites was done by comparison with metabolite standards. Roquefortin $\mathrm{C}$ was visible after spraying with $\mathrm{Ce}\left(\mathrm{SO}_{4}\right)_{2} \mathrm{x} 4$ $\mathrm{H}_{2} \mathrm{O}$ as an orange spot. Cyclopiazonic acid was visible directly in daylight after spraying with the Ehrlich reagent as a violet-tailed spot. Patulin by spraying with $0,5 \%$ methylbenzothiazolone hydrochloride (MBTH, Merck, Germany) in methanol and heating at $130{ }^{\circ} \mathrm{C}$ for $8 \mathrm{~min}$ and then detectable as a yellow-orange spot. Directly under UV light with a wavelength of $365 \mathrm{~nm}$ was visualized citrinin as a yellow-green-tailed spot and griseofulvin as a blue spot.

\section{RESULTS AND DISCUSSION}

The filamentous fungi identified in white grape variety Devín from July 2014 to September 2014 by the direct plating method are indicated in Table 1. Without surface disinfection, a total of 339 strains belonging to 7 genera and Mycelia sterilia were identified. The three most abundant genera found by descending order were Alternaria, Cladosporium and Epicoccum. Trichoderma and Penicillium expansum were detected in more than $1 \%$ of the berries analyzed. The remaining genera were detected in less than $1 \%$ of the berries. Penicillium expansum can cause rot in grapes, but does not usually attack grapes before harvest (Serra et al., 2005). Penicillium expansum was isolated from all 3 maturation stages but in low frequency. Also other studies have identified $P$. expansum as the species most frequently isolated from Portuguese (Abrunhosa et al., 2001) and French (La Guerche et al., 2004; Bejaoui et al., 2006) vineyards.

The mycobiota changed with maturation stage. The most frequent genera by descending order at pea berry were Alternaria, Cladosporium and Epicoccum These constitute $79 \%$ of the fungi identified. The highest incidence of Cladosporium in grape was observed at this stage. Rhizopus occurred only at this stage. The fungal genera most frequently isolated at setting were Alternaria (Bau et al., 2005; Bellí et al., 2006) and Aspergillus (Gomez et al., 2006; Melki Ben Fredj et al., 2007). Cladosporium and Penicillium were isolated less frequently (Bau et al., 2005; Bellí et al., 2006; Gomez et al., 2006; Melki Ben Fredj et al., 2007).

The changes occurred in the incidence of Alternaria, Cladosporium, Epicoccum and Penicillium expansum at early veraison. Alternaria, Epicoccum and Penicillium expansum increased, while the Cladosporium incidence decreased Mucor was detected only at this stage. The most frequent genera by descending order were Alternaria, Cladosporium and Epicoccum, representing $80.5 \%$ of the fungi identified at early veraison.

The changes occurred in the incidence of Alternaria, Cladosporium and Penicillium expansum, which decreased from early veraison to ripe berry. Our results corresponding with Bau et al. (2005), Bellí et al. (2006), Gomez et al. (2006), Melki Ben Fredj et al. (2007). There the percentage of grapes contaminated with Alternaria spp. and Cladosporium spp. also clearly decreased with the ripening of the grape berries. The most frequent genera by descending order were Alternaria, Cladosporium and Epicoccum, representing $71.3 \%$ of the fungi identified at this stage. Trichoderma occurred only at this maturation stage.

Table 1 Fungi identified in white grape variety Devín from July 2014 to September 2014 by the direct plating method

\begin{tabular}{|c|c|c|c|c|c|c|c|c|}
\hline \multirow{2}{*}{ Fungi } & \multicolumn{8}{|c|}{ Number of colonized berries } \\
\hline & Pea berry & $\mathrm{RD}(\%)$ & Early veraison & $\mathrm{RD}(\%)$ & Harvest & $\mathrm{RD}(\%)$ & Total & $\mathrm{RD}(\%)$ \\
\hline Alternaria & 41 & 37 & 58 & 48.3 & 46 & 42.6 & 145 & 42.8 \\
\hline Cladosporium & 37 & 33.3 & 26 & 21.6 & 19 & 17.6 & 82 & 24.2 \\
\hline Epicoccum & 10 & 9 & 12 & 10.0 & 12 & 11.1 & 34 & 10.0 \\
\hline Mucor & 0 & - & 3 & 2.5 & 0 & - & 3 & $<1$ \\
\hline Penicillium expansum & 1 & $<1$ & 2 & 1.7 & 1 & $<1$ & 4 & 1.2 \\
\hline Rhizopus & 1 & $<1$ & 0 & - & 0 & - & 1 & $<1$ \\
\hline Trichoderma & 0 & - & 0 & - & 5 & 4.6 & 5 & 1.5 \\
\hline Mycelia sterilia & 21 & 18.9 & 19 & 15.8 & 25 & 23.1 & 65 & 19.2 \\
\hline Total identified fungi & 111 & & 120 & & 108 & & 339 & \\
\hline
\end{tabular}

Legend: RD - Relative density

The filamentous fungi identified from blue grape variety Frankovka modrá by the direct plating method are indicated in Table 2 . Without surface disinfection, a total of 562 strains belonging to 11 genera and Mycelia sterilia were identified The 4 most abundant genera found by descending order were Alternaria, Cladosporium, Penicillium and Epicoccum. Botrytis cinerea, Fusarium and Trichoderma were detected in more than $1 \%$ of the berries analyzed. Arthrinium, Geotrichum, Mucor and Rhizopus were detected in less than $1 \%$ of the berries. Abrunhosa et al. (2001) reported that Alternaria and Cladosporium were more frequently isolated from red grape varieties than from white grape varieties, regardless of the vineyard in Portugal considered. A total of 114 Penicillium isolates were obtained from healthy red cultivares Frankovka modrá, 12 were obtained at pea berry stage, 23 at early veraison and 79 at ripe berry stage. Based on the results obtained, increasing Penicillium populations were found near harvest in agreement with studies Latorre et al. (2011) and Díaz et al. (2011), however, the overall Penicillium population was considerably less abundant than the populations of Cladosporium spp., which are epiphyte fungi commonly found on grapevines (Latorre et al., 2011).

A total of 181 fungal isolates, representing 7 genera and Mycelia sterilia were identified from pea berry samples. The most frequent genera by descending order at pea berry were Alternaria and Cladosporium, which constitute $69 \%$ of the fungi identified. The highest incidence of Fusarium in grape, which was not detected in white grape variety Devín, was observed at this stage. Healthy cluster 
of Cabernet Sauvignon grapes obtained Penicillium population low in Alhué and Alto Jahuel in Chile (0.006 CFU. $\mathrm{cm}^{-2}$ berry) at the pea-sized berry stage. They increased to 0.009 and 0.12 CFU. $\mathrm{cm}^{-2}$ berry at the beginning of berry ripening stage and to 0.016 and 0.013 CFU. $\mathrm{cm}^{-2}$ of berry at harvest in Alhué and Alto Jahuel, respectively (Díaz et al., 2011) what corresponding with our results.

The highest number of isolates (220) represented 7 genera and Mycelia sterilia was detected at early veraison. The most frequent genera by descending orde were Alternaria, Cladosporium, Epicoccum and Penicillium, representing 83.6\% of the fungi identified at this stage. All of these fungi increased from pea berry to early veraison. The highest incidence of Alternaria, Cladosporium, Epicoccum, Botrytis cinerea and Trichoderma was observed at this stage.

The most frequent genera by descending order were Penicillium, Epicoccum, Alternaria and Cladosporium at harvest stage, representing $85.8 \%$ of the fung identified. Penicillium increased, while Alternaria, Epicoccum and Cladosporium decreased from early veraison to ripe berry. The highest incidence of Penicillium was observed at this stage (49.1\%). Arthrinium, Geotrichum, Mucor and Rhizopus occurred only at maturation stage. At harvest, the most prevalent mycobiota in four French vineyards (Alsace, Beaujolais, Bordeaux and Burgundy) were found to be Penicillium species (Diguta et al., 2011). By contrast, in southern vineyards, black aspergilli have been identified as the predominant mycobiota on grapes at harvest time, although these fungi may be found on the surface of healthy grapes at all stages, regardless of the vineyard considered (Cabañes et al., 2002; Da Rocha Rosa et al., 2002; Sage et al., 2002; Serra et al., 2003; Bellí et al., 2006; Bau et al., 2005; Gomez et al., 2006; Guzev et al., 2006; Leong et al., 2006). The genus Aspergillus is a component of the epiphytic flora of grapes and may be present on grape berries. The surface of infected berries is covered with a black mold that occurs particularly on grapevines growing in warm climates. The symptoms first become evident when lesions are observed on the skin of the berry, they are generally most evident within the grapes after veraison and increase in intensity with berry damage and ripeness (Cabañes et al., 2002; Da Rocha Rosa et al., 2002; Sage et al., 2002; Serra et al., 2003; Bellí et al., 2006; Bau et al., 2005; Gomez et al., 2006; Guzev et al., 2006; Leong et al., 2006; Somma et al., 2012). In the study the genus Aspergillus was not detected in any stages of the grapes growth. The genus Penicillium seems to be more frequent in temperate and cold climates, such as those in northern Europe, whereas Aspergillus is more frequently associated with warmer and wetter regions (Pitt and Hocking, 1997; Battilani et al., 2006; Bejaoui et al., 2006; Serra et al., 2006).

Table 2 Fungi identified in blue grape variety Frankovka modrá from July 2014 to September 2014 by the direct plating method

\begin{tabular}{|c|c|c|c|c|c|c|c|c|}
\hline \multirow{2}{*}{ Fungi } & \multicolumn{8}{|c|}{ Number of colonized berries } \\
\hline & Pea berry & $\mathrm{RD}(\%)$ & Early veraison & $\mathrm{RD}(\%)$ & Harvest & $\mathrm{RD}(\%)$ & Total & $\mathrm{RD}(\%)$ \\
\hline Alternaria & 75 & 41.4 & 80 & 36.4 & 17 & 10.6 & 172 & 30.6 \\
\hline Arthrinium & 0 & - & 0 & - & 1 & $<1$ & 1 & $<1$ \\
\hline Botrytis cinerea & 15 & 8.3 & 17 & 7.7 & 4 & 2.5 & 36 & 6.4 \\
\hline Cladosporium & 50 & 27.6 & 53 & 24.1 & 17 & 10.6 & 120 & 21.3 \\
\hline Epicoccum & 7 & 3.9 & 28 & 12.7 & 25 & 15.5 & 60 & 10.7 \\
\hline Fusarium & 9 & 5.0 & 5 & 2.3 & 3 & 1.9 & 17 & 3.0 \\
\hline Geotrichum & 0 & - & 0 & - & 1 & $<1$ & 1 & $<1$ \\
\hline Mucor & 0 & - & 0 & - & 1 & $<1$ & 1 & $<1$ \\
\hline Penicillium & 12 & 6.6 & 23 & 10.4 & 79 & 49.1 & 114 & 20.3 \\
\hline Rhizopus & 0 & - & 0 & - & 1 & $<1$ & 1 & $<1$ \\
\hline Trichoderma & 4 & 2.2 & 6 & 2.7 & 4 & 2.5 & 14 & 2.5 \\
\hline Mycelia sterilia & 9 & 5.0 & 8 & 3.6 & 8 & 5.0 & 25 & 4.4 \\
\hline Total identified fungi & 181 & & 220 & & 161 & & 562 & \\
\hline
\end{tabular}

Legend: RD - Relative density

Penicillium represents $20.3 \%$ from microfungi in blue grape variety Frankovka modrá in the year 2014. The spectrum of isolated penicillia consisted of 8 species (Table 3). The most presented species of all isolates (114) was P. expansum (73). From this point of view, the relative density was the highest $(64 \%)$.

Four species were detected at pea berry, namely $P$. aurantiogriseum, $P$. brevicompactum, $P$. expansum and $P$. glabrum. The most presented species of all isolates (12) was $P$. expansum $(58.3 \%)$.

Six species were present in the veraison time, namely $P$. aurantiogriseum, $P$. brevicompactum, $P$. corylophilum, $P$. expansum, $P$. glabrum and $P$. polonicum. The largest number of isolates belonged to $P$. expansum $(10,43.5 \% \mathrm{RD}), P$
brevicompactum
$(5$,
$21.7 \%$
$\mathrm{RD})$

P. corylophilum $(3,13.0 \% \mathrm{RD})$. Another isolates were present under $10 \%$.

The genera Penicillium was predominant in harvest time $(49.1 \%)$, and it was represented by $P$. aurantiogriseum P. brevicompactum, $P$. corylophilum, $P$. expansum, $P$. glabrum, $P$. griseofulvum and $P$. chrysogenum. During the harvest time, a number of Penicillium strains belonging to species with ability to produce mycotoxins $(P$. expansum, $P$. griseofulvum and $P$. chrysogenum). They were present with a $73.5 \%$ relative density of 79 Penicillium strains. Penicillium verrucosum and P. nordicum, the only confirmed Penicillium species that are able to produce ochratoxin A, were not isolated.

Fifty-nine different species of Penicillium have been isolated from grapes in vineyards around the world (Rousseaux et al., 2014). The predominant species of Penicillium isolated from grapes differs between vineyards and vintages. For example, $P$. chrysogenum is the species most frequently isolated in Argentina (Magnoli et al., 2003). Penicillium brevicompactum has been identified as the Penicillium species most frequently isolated from French and Portuguese vineyards (Sage et al., 2002, 2004; Serra et al., 2005, 2006). Diguta et al. (2011) identified $P$. spinolusum as the most frequently isolated species of Penicillium, followed by $P$. expansum and P. minioluteum, for the 2008 vintage in Burgundy. La Guerche et al. (2004) identified $P$. expansum as the predominant species isolated from Bordeaux vineyards. Thus, the distribution of Penicillium species, which may generate organoleptic defects, depends on both vineyard and vintage. It is therefore likely to be difficult to generalize the management of filamentous fungus control (Rousseaux et al., 2014).

Table 3 Penicillium species identified in blue grape variety Frankovka modrá from July 2014 to September 2014

\begin{tabular}{|c|c|c|c|c|c|c|c|c|}
\hline \multirow{2}{*}{ Penicillium species } & \multicolumn{8}{|c|}{ Number of colonized berries } \\
\hline & Pea berry & $\mathrm{RD}(\%)$ & Early veraison & $\mathrm{RD}(\%)$ & Harvest & $\mathrm{RD}(\%)$ & Total & $\mathrm{RD}(\%)$ \\
\hline P. aurantiogriseum & 2 & 16.7 & 1 & 4.3 & 3 & 3.8 & 6 & 5.3 \\
\hline P. brevicompactum & 2 & 16.7 & 5 & 21.7 & 7 & 8.9 & 14 & 12.3 \\
\hline P. corylophilum & 0 & - & 3 & 13.0 & 7 & 8.9 & 10 & 8.8 \\
\hline P. expansum & 7 & 58.3 & 10 & 43.5 & 56 & 70.9 & 73 & 64.0 \\
\hline P. glabrum & 1 & 8.3 & 2 & 8.7 & 4 & 5.1 & 7 & 6.1 \\
\hline P. griseofulvum & 0 & - & 0 & - & 1 & 1.3 & 1 & $<1$ \\
\hline P. chrysogenum & 0 & - & 0 & - & 1 & 1.3 & 1 & $<1$ \\
\hline P. polonicum & 0 & - & 2 & 8.7 & 0 & - & 2 & 1.7 \\
\hline Total & 12 & & 23 & & 79 & & 114 & \\
\hline
\end{tabular}

Legend: RD - Relative density

In total 14 Penicillium strains representing 3 potentially toxigenic species were tested for their toxigenic ability, namely $P$. expansum, $P$. griseofulvum and $P$. chrysogenum (Table 4). Of all potentially toxigenic strains $P$. expansum from white grape variety Devín and $P$. chrysogenum from blue grape variety 
Frankovka modrá were positive on tested mycotoxins. A $50 \%$ of P. expansum from Frankovka modrá were positive for citrinin, a higher percentage $(80 \%)$ of isolates were positive for patulin and all were positive for roquefortin $\mathrm{C}$. A small percentage $(20 \%)$ of $P$. expansum isolates were positive for patulin on YES agar, whereas they were all positive for citrinin, reported Abrunhosa et al. (2001) from the wine-producing regions of Portugal. Penicillium griseofulvum from Frankovka modrá was positive for griseofulvin, cyclopiazonic acid and roquefortin $\mathrm{C}$ but not for patulin. Out of 14 strains, 64\% produced et least one mycotoxin as revealed by the method used here. Patulin, produced primarily by $P$. expansum is a thermal resistant, causes gastrointestinal problems, skin rashes, and is known to be mutagenic, immunologic, and neurotoxic mycotoxin (Abrunhosa et al., 2001). Patulin contaminates apples and apple derivates (Frisvad and Flitenborg, 1989). However, patulin has also been reported in grapes (Moake et al., 2005), processed grape juice and fermenting wine (Majerus et al., 2008). Patulin inhibits the fermenting yeast Saccharomyce cerevisiae in the must. It is partially degraded by the addition of sulfur dioxide and completely degraded during alcoholic fermentation (Ough and Corison, 1980; Díaz et al., 2011). It is therefore unlikely to be present in wine. Citrinin is a nephrotoxic mycotoxin produced by several species of the genera Aspergillus, Penicillium and Monascus. Penicillium citrinum, the main producer of citrinin, was not isolat from our grapes. Citrinin is not degraded during alcoholic fermentation and may be present in very small amounts in wine. However, wine contamination is unlikely, due to the low abundance of citrinin producing species on grapes.

$\underline{\text { Table } 4 \text { Toxinogenity of selected Penicillium strains isolated from grapes }}$

\begin{tabular}{|c|c|c|c|c|c|c|}
\hline $\begin{array}{l}\text { Penicillium } \\
\text { species }\end{array}$ & Isolated from & $\mathrm{C}$ & $\mathrm{P}$ & G & CPA & $\mathrm{RC}$ \\
\hline P. expansum & Devín & $2 * / 2 * *$ & $2 / 2$ & & & $2 / 2$ \\
\hline P. expansum & $\begin{array}{l}\text { Frankovka } \\
\text { modrá }\end{array}$ & $5 / 10$ & $8 / 10$ & & & $10 / 10$ \\
\hline P. griseofulvum & $\begin{array}{l}\text { Frankovka } \\
\text { modrá }\end{array}$ & & $0 / 1$ & $1 / 1$ & $1 / 1$ & $1 / 1$ \\
\hline P. chrysogenum & $\begin{array}{l}\text { Frankovka } \\
\text { modrá }\end{array}$ & & & & & $1 / 1$ \\
\hline
\end{tabular}

Legend: $\mathrm{C}$ - citrinin; $\mathrm{P}$ - patulin; $\mathrm{G}$ - griseofulvin; $\mathrm{CPA}$ - cyclopiazonic acid;

$\mathrm{RC}$ - roquefortin $\mathrm{C} ;{ }^{*}$ positive isolates; ${ }^{* *}$ number of tested isolates

\section{CONCLUSION}

Two grape varieties Devín and Frankovka modrá (Blue Frankish) were collected in the maturation stages corresponding to pea berry, early veraison and harvest from the Nitra wine region. Samples were mycological analysed with focus on genera Penicillium. The mycobiota changed with maturation stage. The most presented genera by descending order at pea berry and early veraison were Alternaria, Cladosporium and Epicoccum and at ripe berry Alternaria, Cladosporium and Penicillium expansum. Penicillium contamination in all stage types of grapes Devín was lower than in Frankovka modrá grape variety, where 79 isolates of 7 Penicillium species were found. Moulds commonly isolated from grape variety Frankovka modrá were Alternaria, Cladosporium and Penicillium. Results indicate that Penicillium expansum is the major species of Penicillium found on grapevins that can potentionally contaminate grapes with patulin However, the average relative density of patulin-producing strains of $P$. expansum in grapes variety Devín was relatively low $(1.2 \%)$ but in blue grapes higher $(20.3 \%)$. Three potentially toxigenic species isolated from exogenous mycobiota were tested for their toxigenic ability by thin layer chromatography method, namely $P$. expansum, $P$. griseofulvum and $P$. chrysogenum. Out of 14 strains, $64 \%$ produced at least one mycotoxin. In the research, ochratoxigenic microfungi were not found in grape samples. The use of good quality raw materials is essential for mycotoxin control in food products.

Acknowledgments: The research leading to these results has received funding from the European Community under project no 26220220180: Building Research Centre „AgroBioTech".

\section{REFERENCES}

Abrunhosa, L., Paterson, R.R., Kozakiewicz, Z., Lima, N. \& Venâncio, A. (2001). Mycotoxin production from fungi isolated from grapes. Letters in Applied Microbiology, $32(4)$ 240-242.http://dx.doi.org/10.1046/j.1472 765x.2001.00897.x

Barata, A., Malfeito-Ferreira, M. \& Loureiro, V. (2012). The microbial ecology of win grape berries. International Journal of Food Microbiology, 153(3), 243 259. http://dx.doi.org/10.1016/j.ijfoodmicro.2011.11.025

Barkai-Golan, R. (2001). Postharvest Diseases of Fruits and Vegetables. Amsterdam : Elsevier, 442 p. ISBN 9780444505842.

Battilani, P., Giorni, P., Bertuzzi, T., Formenti, S. \& Pietri, A. (2006). Black aspergilli and ochratoxin A in grapes in Italy. International Journal of Food Microbiology, 111(6), 53-60. http://dx.doi.org/10.1016/j.ijfoodmicro.2006.03.006
Bau, M., Bragulat, M.R., Abarca, M.L., Minguez, S. \& Cabañes, F.J. (2005) Ochratoxigenic species from Spanish wine grapes. International Journal of Food Microbiology, $98(2)$

http://dx.doi.org/10.1016/j.ijfoodmicro.2004.05.015

Bejaoui, H., Mathieu, F., Taillandier, P. \& Lebrihi, A. (2006). Black aspergilli and ochratoxin A production in French vineyards. International Journal of Food Microbiology, 111(6), 46-52. http://dx.doi.org/10.1016/i.ijfoodmicro.2006.03.004 Bellí N., Bau, M., Marín, S., Abarca, M. L., Ramos, A. J. \& Bragulat, M. R. (2006). Mycobiota and ochratoxin A producing fungi from Spanish wine grapes. International Journal of Food Microbiology, 111(6), 40-45. http://dx.doi.org/10.1016/j.ijfoodmicro.2006.03.011

Cabañes, F.J., Accensi, F., Bragulat, M.R., Abarca, M.L., Castellá, G., Minguez, S. \& Pons, A. (2002). What is the source of ochratoxin A in wine? International Journal of Food Microbiology, 79(3), 213-215. http://dx.doi.org/10.1016/s0168 1605(02)00087-9

Clouvel, P., Bonvarlet, L., Martinez, A., Lagouarde, P., Dieng, I. \& Martin, P. (2008). Wine contamination by ochratoxin A in relation to vine environment. International Journal of Food Microbiology, 123(1-2), 74-80. http://dx.doi.org/10.1016/j.ijfoodmicro.2007.12.003

Da Rocha Rosa, C.A., Palacios, V., Combina, M., Fraga, M.E., De Oliveira Rekson, A., Magnoli, C.E. \& Dalcero, A.M. (2002). Potential ochratoxin A producers from wine grapes in Argentina and Brazil. Food Additives and Contaminants, 19(4), 408-414. http://dx.doi.org/10.1080/02652030110092748 Diaz, G.A., Yanez, L. \& Latorre, B.A. (2011). Low occurrence of patulinproducing strains of Penicillium in grapes and patulin degradation during winemaking in Chile. American Journal of Enology and Viticulture, 62(4), 542 546. http://dx.doi.org/10.5344/ajev.2011.11034

Diguta, C.F., Vincent, B., Guilloux-Benatier, M., Alexandre, H. \& Rousseau, X.S. (2011). A useful methods for identifying filamentous fungi isolates on $\begin{array}{llll}\text { grapes. } & \text { Food } & \text { Microbiology, } & \text { 28(6), }\end{array}$ http://dx.doi.org/10.1016/j.fm.2011.03.006

Donoso, A. \& Lattore, B.A. (2006). Characterization of blue mold caused by Penicillium spp. in cold stored table grapes. Ciencia e Investigatión Agraria 33(2), 119-130.

Frisvad, J.C., Flitenborg, O. (1989). Terverticillate penicillia: Chemotaxonomy

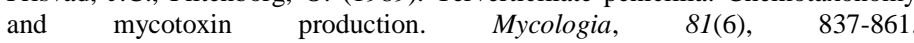
http://dx.doi.org/10.2307/3760103

Gomez, C., Bragulat, M.R., Abarca, M.L., Minguez, S. \& Cabanes, F.J. (2006) Ochratoxin A-producing fungi from grapes intended for liqueur wine production Food Microbiology, 23(6), 541-545. http://dx.doi.org/10.1016/j.fm.2005.09.007 González, H. H. L., Martínez, E. J., Pacin, A. \& Resnik, S. L. (1999) Relationship between Fusarium graminearum and Alternaria alternata contamination and deoxinivalenol occurrence on Argentinian durum wheat Mycopathologia, 144(2), 97-102. http://dx.doi.org/10.1023/a:1007020822134 Guatam, A., Sharma, S. \& Bhadauria, R. (2009). Detection of toxigenic fungi and mycotoxins in medicinally important powdered herbal drugs. Internet Journal of Microbiology, 7(2).

Guzev, L., Danshin, A., Ziv, S. \& Lichter, A. (2006). Occurrence of ochratoxin A producing fungi in wine and table grapes in Israel. International Journal of Food Microbiology, http://dx.doi.org/10.1016/j.ijfoodmicro.2006.03.003

La Guerche, S., Gracia, C., Darriet, P., Dubourdieu, D. \& Labarère, J. (2004) Characterization of Penicillium species isolated from grape berries by their internal transcribed spacer (ITS1) sequences and by gas chromatography-mass spectrometry analysis of geosmin production. Current Microbiology, 48(4), 405411. http://dx.doi.org/10.1007/s00284-003-4176-4

Labuda, R. \& Tančinová, D. (2006). Fungi recovered from Slovakian poultry feed mixtures and their toxinogenity. Annals of Agricultural and Environmental Medicine, 13(2), 193-200.

Lasram, S., Barketi, A., Mliki, A \& Ghorbel, A. (2012). Growth and ochratoxin A production by Aspergillus carbonarius at different $\mathrm{pHs}$ and grape maturation stages. Letters in Applied Microbiology, 54(5), 418-524. http://dx.doi.org/10.1111/j.1472-765x.2012.03224.x

Latorre, B.A., Briceño, E.X. \& Torres, R. (2011). Increase in Cladosporium spp. population and rot of wine grapes associated with leaf removal. Crop Protection. 30(1), 52-56. http://dx.doi.org/10.1016/j.cropro.2010.08.022

Leong, S.L., Hocking, A.D., Pitt, J.I., Kazi, B.A., Emmett, R.W. \& Scott, E.S (2006). Australian research on ochratoxigenic fungi and ochratoxin A International Journal of Food Microbiology, 111(6), 10-17. http://dx.doi.org/10.1016/j.ijfoodmicro.2006.02.005

Magnoli, C., Violante, M., Combina, M., Palacio, G. \& Dalcero, A. (2003). Mycoflora and ochratoxin-producing strains of Aspergillus section Nigri in wine grapes in Argentina. Letters in Applied Microbiology, 37(2), 179-184. http://dx.doi.org/10.1046/j.1472-765x.2003.01376.x

Majerus, P., Hain, J. \& Köld, C. (2008). Patulin in grape must and new, still fermenting wine (Federweiber). Mycotoxins Research, 24(3), 135-139. http://dx.doi.org/10.1007/bf03032340

Melki Ben Fredj, S., Chebil, S., Lebrihi, A., Lasram, S., Ghorbel, A. \& Mliki, A (2007). Occurrence of pathogenic fungal species in Tunisian vineyard 
International Journal of Food Microbiology, 113(3), 245-250. http://dx.doi.org/10.1016/j.ijfoodmicro.2006.07.022

Moake, M.M., Padilla-Zakour, O.I. \& Worobo, R.W. (2005). Comprehensive review of patulín control methods in foods. Comprehensive Reviews in Food Science and Food Safety, 4(1), 8-21. http://dx.doi.org/10.1111/j.15414337.2005.tb00068.x

Ough, C.S. \& Corison, C.A. (1980). Measurement of patulin in grapes and wines. Journal of Food Science, 45(3), 476-478. http://dx.doi.org/10.1111/j.13652621.1980.tb04079.x

Pitt, J. I. \& Hocking, A. D. (1997). Fungi and food spoilage. 2nd ed. London : Blackie Academic \& Professional, 593 p. ISBN 0-8342-1306-0. http://dx.doi.org/10.1007/978-1-4615-6391-4

Rosa, C.A., Palácios, V., Combina, M., Fraga, M.E., Oliveira Rekson, A., Magnoli, C.E. \& Dalcero, A.M. (2002). Potential ochratoxin A producers from wine grapes in Argentina and Brazil. Food Additives and Contaminants, 19(4), 408-414. http://dx.doi.org/10.1080/02652030110092748

Rousseaux, S., Diguta, C.F., Radoï-Matei, F., Alexandre, H. \& GuillouxBénatier, M. (2014). Non-Botrytis grape-rotting fungi responsible for earthy and moldy off-flavors and mycotoxins. Food Microbiology, 38, 104-121. http://dx.doi.org/10.1016/j.fm.2013.08.013

Sage, L., Krivobok, S., Delbos, E., Seigle-Murandi, F. \& Creppy, E.E. (2002) Fungal flora and ochratoxin A production in grapes and musts from France. Journal of Agricultural and Food Chemistry, 50(5), 1306-1311. http://dx.doi.org/10.1021/jf011015z

Sage, L., Garon, D. \& Seigle-Murandi, F. (2004). Fungal microflora and ochratoxin A risk in french vineyards. Journal of Agricultural and Food Chemistry, 52(18), 5764-5768. http://dx.doi.org/10.1021/jf049497c

Samson, R.A. \& Frisvad, J.C. (2004). Polyphasic taxonomy of Penicillium subgenus Penicillium: new taxonomic schemes, mycotoxins and other extrolites. Studies in Mycology 46, Utrecht, The Netherlands : Centraalbureau voor Schimmelcultures, $260 \mathrm{p}$. ISBN 90-70351-53-6.

Samson, R. A., Hoekstra, E. S., Frisvad, J. C. \& Filtenborg, O. (2002a) Introduction to food- and airborne fungi. Utrecht : Centraalbureau voor $\begin{array}{lllll}\text { Schimmelcultures, } & 389 & \text { p. } & \text { ISBN } & 90-70351-42-0\end{array}$ http://dx.doi.org/10.1007/s11046-005-4201-1

Samson, R. A., Hoekstra, E. S., Lund, F., Filtenborg, O. \& Frisvad, J. C. (2002b) Method for the detection, isolation and characterisation of food-borne fungi. In SAMSON, R. A., HOEKSTRA, E. S., FRISVAD, J. C., FILTENBORG, O. Introduction to food- and airborne fungi. Utrecht : Centraalbureau voor Schimmecultures, 283-297. ISBN $\quad$ 90-70351-42-0. http://dx.doi.org/10.1007/s11046-005-4201-1

Samson, R. A., Houbraken, J., Thrane, U., Frisvad, J. C. \& Andersen, B. (2010). Food and Indoor Fungi. Utrecht : CBS - KNAW Fungal Biodiversity Centre, 390 p. ISBN 978-90-70351-82-3.

Serra, R., Abrunhosa, L., Kozakiewicz, Z. \& Venâncio, A. (2003). Black Aspergillus species as ochratoxin A producers in Portuguese wine grapes. International Journal of Food Microbiology, 88(1), 63-68. http://dx.doi.org/10.1016/s0168-1605(03)00085-0

Serra, R., Lourenco, A., Alipio, P. \& Venâncio, A. (2006). Influence of the region of origin on the mycobiota of grapes with emphasis on Aspergillus and Penicillium species. Mycological research, 110(8), 971-978. http://dx.doi.org/10.1016/j.mycres.2006.05.010

Serra R, Braga A., \& Venâncio A. (2005). Mycotoxin-producing and other fungi isolated from grapes for wine production, with particular emphasis on ochratoxin A. Research in Microbiology, 156(4), 515-521. http://dx.doi.org/10.1016/j.resmic.2004.12.005

Somma, S., Perrone, G. \& Logrieco, A.F. (2012). Diversity of black Aspergilli and mycotoxin risks in grape, wine and dried vine fruits. Phytopathologia Mediterranea, 51(1), 131-147.

Tournas, V.H. \& Katsoudas, E. (2005). Mould and yeast flora in fresh berries, grapes and citrus fruits. International Journal of Food Microbiology, 105(1), 1117. http://dx.doi.org/10.1016/j.ijfoodmicro.2005.05.002

Valero, A., Marín, S., Ramos, A.J. \& Sanchis, V. (2005). Ochratoxin Aproducing species in grapes and sun-dried grapes and their relation to ecophysiological factors. Letters in Applied Microbiology, 41(2), 196- 201. http://dx.doi.org/10.1111/j.1472765x.2005.01705.x 